Tarbawy : Jurnal Pendidikan Islam

ISSN : 2407-4462 (Cetak), 2614-5812 (Elektronik)

Vol. 7, No. 1, 2020, Hal. 33-41

DOI: https://doi.org/ 10.32923/tarbawy.v7i1.1176

\title{
Jejak Kebangkitan SD Muhammadiyah Tertua Dibumi Serumpun Sebalai
}

\author{
Muhammad Iqbal Arrosyad ${ }^{1}$, Sri Sugiarti ${ }^{2}$ \\ ${ }^{1}$ STKIP Muhammadiyah Bangka Belitung \\ ${ }^{2}$ STKIP Muhammadiyah Bangka Belitung
}

\begin{tabular}{l}
\hline Info Artikel : \\
\hline Diterima 31 Maret 2020 \\
Direvisi 20 April 2020 \\
Dipublikasikan 27 April 2020
\end{tabular}

Kata Kunci:
Jejak Kebangkitan
SD Muhammadiyah
Keywords:
Traces of the Resurrection
Muhammadiyah Elementary
School

\section{Koresponden:}

Muhammad Iqbal Arrosyad,

Email: arrosyadiqbal@gmail.com

\begin{abstract}
ABSTRAK
Penelitian ini bertujuan untuk mendeskripsikan bagaimana sejarah berdirinya SD Muhammadiyah yang difokuskan di SD Muhammadiyah Pangkalpinang sebagai SD Muhammadiyah tertua di Bumi Serumpun Sebalai atau Bangka Belitung, mendeskripsikan kendala yang menjadi sejarah kebangkitan SD Muhammadiyah tertua di Bumi Serumpun Sebalai, dan mendeskripsikan bagaimana pengelolaan menajemen sekolah. Penelitian ini merupakan penelitian deskriptif dengan pendekatan kualitatif. Teknik pengumpulan data yang digunakan yakni wawancara, dokumentasi dan observasi lapangan. Sampel yang digunakan merupakan Sekolah Dasar tertua yang ada di Bumi Serumpun Sebalai atau Kepulauan Bangka Belitung yakni SD Muhammadiyah Pangkalpinang. Hasil peneilitian ini menjelaskan bahwa SD Muhammadiyah pangkalpinang berdiri sejak tahun 1960 masehi, kendala yang menjadi sejarah besar yakni terjadinya pemisahan sekolah Muhammadiyah menjadi SD Muhammadiyah 1 dan SD Muhammadiyah 2 dan juga terjadinya banjir besar, pengelolaan sekolah sangat beragam dengan adanya pergantian kepala sekolah yang berkesinambungan sampai dengan sekarang.
\end{abstract}

\section{ABSTRACT}

This study aims to describe how the history of the founding of Muhammadiyah Elementary School which is focused on the Muhammadiyah Elementary School in Pangkalpinang as the oldest Muhammadiyah Elementary School in the Earth Serumpun Sebalai or Bangka Belitung, describes the obstacles that became the history of the revival of the oldest Muhammadiyah Elementary School in Sebalai Serumpun Earth and describe how the management of school management. This research is a descriptive study with a qualitative approach. Data collection techniques used were interviews, documentation and field observations. The sample used is the oldest elementary school in Bumi Serumpun Sebalai of Bangka Belitung Islands, namely Muhammadiyah Elementary School, Pangkalpinang. The results of this study explain that Muhammadiyah elementary school in Pangkalpinang was founded in 1960 AD, a major historical obstacle is the separation of Muhammadiyah schools into Muhammadiyah 1 and SD Muhammadiyah 2 schools and also the occurrence of major flooding, the school management is very diverse with the continuous change of school principals until with now.

(C) This is an open access article distributed under the Creative Commons Attribution License, which permits unrestricted use, distribution, and reproduction in any medium, provided the original work is properly cited. (2019 by author.

\section{Pendahuluan}

Sejarah pendidikan di Indonesia telah berjalan sangat jauh, dari masa penjajahan yang mana memerlukan perjuangan berat untuk dapat pergi ke sekolah sampai masa milenial yakni masa dimana pendidikan sudah tersebar luar disetiap daerah bahkan pendidikan dapat dilakukan di dalam rumah menggunakan alat komunikasi yang canggih. Sejarah telah membuktikan bahwa pendidikan bangsa Indonesia telah mengalami perkembangan dan juga kemajuan mengikuti jaman. Dengan bukti pendidikan merupakan landasan yang perlu dilakukan supaya dapat melangsungkan kehidupan yang lebih baik.

Pendidikan di Indonesia telah membuktikan bahwa pendidikan adalah alat penting yang menjadi perjuangan dalam mencapai kemerdekaan, semangat perjuangan, maupun pengembangan nasional. Perjuangan pada masa penjajahan yang menggunakan semangat dalam pendidikan sudah dimulai sejak masa pergerakan kebangsaan sekitar dasawarsa pertama pada abad XX. Dan juga pembangunan satu kesatuan sistem pendidikan dilaksanakan sesudah pecapaian kemerdekaan untuk mewujudkan cita-cita negara kebangsaan yang dapat melindungi pemerintah Republik Indonesia. Seperti yang disampaikan 
(Anshori, 2016) pada masa pembangunan dewasa ini, pengembangan sistem pendidikan nasional telah semakin maju dan diharapkan lebih dapat memberikan kemakmuran bagi warganya, di samping persatuan dan kesatuan bangsa serta pembentukan kepribadian dan budaya bangsa.

(Dahlan, 2014) menyatakan tentang organisasi Muhammadiyah adalah.organisasi yang bergerak pada bidang keagamaan dengan berbagai arah termasuk di bidang pendidikan. Organisasi Muhammdiyah yang telah didirikan K.H. Ahmad Dahlan menjadi salah satu gerakan organisasi yang berperan untuk meningkatkan mutu pendidikan di Indonesia. Seperti yang disampaikan (Mafidin, 2012) mengenai arti penting berdirinya Muhammadiyah saat itu adalah pertama, pergulatan pendidikan dalam masa pergerakan kebangsaan menjadi memiliki basis yang luas bagi masyrakat pribumi; kedua, semangat dan nilai-nilai keagamaan (Islam) ikut mewarnai dan menjadi basis pergerakan kebangsaan. Muhammadiyah sebagai organisasi keagamaan mengarahkan kegiatannya pada pemurnian keyakinan dan pelaksanaan ajaran Islam di kalangan umat yang saat itu mengalami penyimpangan, kejenuhan, kemandegan, serta kemerosotan.

Muhammadiyah merupakan gerakan sosial keagamaan modernis, (Hadi, 2005) menyatakan Muhammadiyah sering disebut sebagai gerakan pembaharuan atau sosio-religius, hal ini seiring perjalanan terbentuknya dan perkembangannya di Indonesia. Dengan demikian gerakan organisasi Muhammadiyah berperan baik dalam kemajuan kemasyarakatn Indonesia dibidang pendidikan.

Pendidikan Muhammadiyah telah mengalami perkembangan dan sudah tersebar luas keseluruh Indonesia diantaranya di Kepulauan Bangka Belitung atau biasa disebut Bumi Serumpun Sebalai. Pendidikan jenjang Sekolah Dasar Muhammadiyah yang ada di Bumi Serumpun Sebagai terdapat sebanyak 7 sekolah. Berdasarkan hasil pengumpulan data peneliti, Sekolah Dasar tertua yakni SD Muhammadiyah Pangkalpinang.

Sejarah pendidikan SD Muhammadiyah Pangkal Pinang merupakan SD Muhammadiyah tertua yang ada di kepulauan Bangka Belitung. Berdasarkan hasil observasi yang dilalukan, jejak perkembangan pendidikan SD Muhammadiyah Pangkalpinang hilang, hal itu dikarenakan terjadi bencana alam banjir bandang yang mengakibatkan semua berkas dan dokumen hilang atau hanyut. Kejadikan tersebut akan menjadi bahan pembahasan pada penelitian ini.

Dalam penelitian ini, peneliti membahas mengenai bagaimana sejarah berdirinya SD Muhammadiyah yang difokuskan di SD Muhammadiyah Pangkalpinang sebagai SD Muhammadiyah tertua di Bumi Serumpun Sebalai atau Bangka Belitung, mendeskripsikan kendala yang menjadi sejarah kebangkitan SD Muhammadiyah tertua di Bumi Serumpun Sebalai, dan mendeskripsikan bagaimana pengelolaan menejemen sekolah.

\section{Metode}

Penelitian ini menggunakan metode deskriptif dengan pendekatan kualitatif, seperti yang disampaikan (Somantri, 2005) mendefinisikan penelitian kualitatif sebagai prosedur penelitian yang menghasilkan data deskriptif berupa kata-kata tertulis atau lisan dari orang-orang dan perilaku yang diamati dari fenomena yang terjadi. Pendekatan yang digunakan yakni pendekatan sosiologi pendidikan yang lebih terfokus pada sebuah peristiwa sejarah akan dilihat sebagai sebuah fenomena social.

Teknik pengumpulan data yang digunakan yakni dokumentasi terkait foto dan pengumpulan data penting, observasi lapangan untuk mengamati secara langsung situasi terbaru atau nyata, dan wawancara mendalam dengan subjek pengurus dan mantan pengurus dari SD Muhammadiyah Pangkalpinang seperti kepala-kepala sekolah terdahulu dan pengurus dari sekolah tersebut. Hasil dari pengumpulan data kemudian dialaisis secara terperinci dengan Teknik triangulasi data sehingga diakhr dari analisis menghasilkan penjabaran yang singkat, terperinci namun jelas

\section{Hasil dan Pembahasan}

Berdasarkan jenjang pendidikannya bahwa berdirinya sekolah Muhammadiyah pertama kali adalah Sekolah Dasar Muhammadiyah di Pangkalpinang yang berdiri tahun1962, disusul SD Muhammadiyah Muntok yang berdiri tahun 1962, disusul pembukaan SD Muhammadiyah Sungailiat tahun 1967. Untuk tingkat sekolah dasar tiga sekolah ini menjadi sekolah paling lama karena baru didirikan kembali untuk sekolah tingkat dasar mulai tahun 2000-an, dimulai dengan dibukanya SD Muhamamdiyah 1 Tanjungpandan tahun 2007, kemudian SD Muhammadiyah Tanjungpandan 2 tahun 2012. Selanjutnya juga dibuka sekolah Labschoolnya STKIP Muhammadiyah namun lebih dikenal dengan SD STKIP Muhammadiyah pada tahun 2016 dan terakhir tahun 2017 SD Muhammadiyah Toboali turut 
menyemarakkan dunia pendidikan di Bumi Serumpun Sebalai. Untuk lebih jelasnya bisa dilihat di tabel dibawah ini:

Tabel 1 Sekolah Dasar Muhammadiyah di Bangka Belitung

\begin{tabular}{ccc}
\hline No & Nama Sekolah & Tahun Berdiri \\
& & \\
1 & SD Muhammadiyah Pangkalpinang & 1960 \\
2 & SD Muhammadiyah Muntok & 1962 \\
3 & SD Muhammadiyah Sungailiat & 1967 \\
4 & SD Muhamadiyah 1 Tanjung Pan & 2007 \\
5 & SD Muhammadiyah 2 Tanjungpandan & 2012 \\
6 & SD STKIP Muhammadiyah & 2016 \\
7 & SD Muhammadiyah Toboali & 2017 \\
\hline
\end{tabular}

Sekolah Dasar (SD) Muhammadiyah Pangkalpinang merupakan sekolah Muhammadiyah tertua di Bangka Belitung berdasarkan angket yang disebarkan. Sementara pemilihan menjadi sekolah terbaik berdasarkan jumlah murid, nilai ujian akhir selama tiga tahun terakhir, prestasi bidang akademik dan non akademik serta sarana dan prasarana sekolah. Terletak di tengah kota menjadikan lokasi ini sangat strategis. SD ini terletak di Jalan KH. Abdul Hamid Nomor 3 Kelurahan Rawa Bangun Kecamatan Tamansari Kota Pangkalpinang. Sekolah ini telah didirikan sejak tahun 1952, memiliki luas tanah $3200 \mathrm{~m} 2$ dengan jumlah seluruh peserta didik kelas 1 sampai kelas 6 tahun 2018 sebanyak 563 siswa. Sekolah ini juga melaksanakan budaya pembiasaan setiap pagi seperti membaca bacaan sholat dan surah surah bersamaan yang dipimpin oleh guru bersangkutan. Selain itu, pada siang hari peserta didik melaksanakan shalat dzuhur secara berjamaah. (Azimmi, 2019) juga menyatakan bahwa program sekolah dengan mengembangkan budaya pebiasaan pagi sampai akhir pembelajaran dapat meningkatkan karakter religious peserta didik.

\section{Jejak Berdirinya SD Muhammadiyah Pangkalpinang}

Sekolah ini didirikan oleh tokoh-tokoh Muhammadiyah Kota Pangkalpinang, diantaranya KH Hasan Basri Sulaiman, bersama majlis Pendidikan Muhammadiyah. Berdasarkan ijin operasional SK No 711/I017/SM.S-60/1978 tanggal 31 Maret 1978 dan SK pendirian E-1/077/12.1977. Berdasarkan wawancara dengan salah satu guru yang mengajar di awal berdirinya SD Muhammadiyah yakni Muhammad Said A.MD sebagai pengajar dari tahun 1970 sampai tahun 1993 bahwa pengurus awal SD Muhammadiyah diantaranya Ibu Akmar orang padang dan sekarang di Palembang. Ibu Akmar pada jaman tahun 1950an itu awal adanya gerakan Muhammadiyah sehingga mengalami benar-benar perjuangan dengan orang yang seadanya, karena masih sedikit juga sehingga kebanyakan dari pendatang pengurus Muhammadiyah, dan salah satunya Ibu Akmar asli Padang dan menjadi pengurus pertama SD Muhammadiyah Pangkalpinang pada tahun 1952. Perkembangan SD dari mulai berdiri semakin maju hal ini terbukti dari makin banyaknya siswa yang masuk ke sekolah ini. Perkembangan SD Muhammadiyah benar-benar dirombak dan diperbaiki dari kepengurusan, sistem pembelajaran, sampai program-program di SD Muhammadiyah Pangkalpinang (Danil, 2009).

Prestasi siswa yang lulus dari SD Muhammadiyah Pangkalpinang juga gemilang dikarenakan guruguru yang sesuai dengan ahlinya. Hasil dari prestasi siswa yang baik di SD Muhammadiyah Pangkalpinang membuat masyarakat mulai melirik dan menilai tentang SD Muhammadiyah Pangkalpinang. Tidak hanya dari kalangan menengah ke bawah, akan tetapi juga dari kalangan menengah ke atas. Selain pandangan masyarakat terhadap hasil prestasi siswa di SD Muhammadiyah Pangkalpinang, masyarakat juga menilai dari segi mata pelajaran yang diberikan di SD Muhammadiyah Pangkalpinang berbeda dengan SD Negeri pada umumnya. Jika SD Negeri pada umumnya mengutamakan mata pelajaran muatan lokal yang terdiri dari mata pelajaran Matematika, IPA, Bahasa Indonesia, Bahasa Inggris, dan lain-lain. Akan tetapi jika di SD Muhammadiyah Pangkalpinang mendapatkan tambahan mata pelajaran Al-Islam dan Kemuhammadiyahan (Zalik Nuryana, 2017) yakni mata pelajaran Agama, Bahasa Arab, Fiqih, dan Ibadah.

Materi pembelajaran umum yang ada di SD Muhammadiyah Pangkalpinang waktu itu menjadi saingan bagi SD Negeri lainnya. Sehingga dapat menjadi perhitungan tersendiri bagi masyarakat, walaupun SD swasta akan tetapi sudah bisa bersaing dengan SD negeri dan bahkan memiliki nilai tambah lain, yakni terdapat pelajaran agamanya. Dari situlah masyarakat mulai tertarik dan menilai baik ke SD Muhammadiyah Pangkapinang untuk menyekolahkan anak-anaknya. Mulai tahun 1980-an perkembangan 
SD Muhammadiyah Pangkalpinang semakin baik. Sampai pada tahun berikut-berikutnya pergantian kepengurusan dan bahkan sekarang pada tahun 2019 kepala sekolah SD Muhammadiyah Pangkalpinang merupakan lulusan SD Muhammadiyah Pangkalpinang yang dulu murid dari Bapak Said Muhammad.

\section{Kendala yang Mejadi Sejarah Kebangkitan SD Muhammadiyah Pangkalpinang}

Wawancara dengan mantan Kepala Sekolah Supanut menyatakan siswa SD Muhammadiyah Pangkalpinang pada tahun 1977 sampai tahun 1980 tercatat sampai 400-an siswa, kemudian pada tahun 1980-an sampai tahun 1985 siswa bertambah sampai 600-700 siswa dan melebihi target. Sehingga sekitar tahun 1982 itu SD Muhammadiyah Pangkalpinang dibagi menjadi dua Sekolah Dasar yakni SD Muhammadiyah 1 dan SD Muhammadiyah 2 Pangkalpinang, dengan tujuan agar pengelolaan sekolah dapat lebih baik lagi.

Lokasi SD Muhammadiyah 1 Pangkalpinang dan SD Muhammadiyah 2 Pangkalpinang sama, hanya waktu belajar yang berbeda. Pelaksanaan pembelajaran di bagi dua, SD Muhammadiyah 1 Pangkalpinang dilaksanakan di waktu pagi sampai siang, sedangkan SD Muhammadiyah 2 Pangkalpinang dilaksanakan diwaktu siang sampai sore. Pembagian waktu ini dikarenakan pendaftaran SD Muhamadiyah Pangkalpinang sebelumnya sangat banyak dan memerlukan ruang yang banyak sedangkan pembelajaran harus tetap dilaksanakan. Dengan keputusan dan hasil musyawarah dan dengan ketidak mungkinan untuk menambah ruang dengan waktu yang sangat singkat, maka di pisah menjadi dua siswanya dan dengan kepengurusan yang berbeda akan tetapi dibawah naungan yang sama, dari Majelis Dikdasmen Muhammadiyah.

Bapak Supanut tahun 1986 awal mula menjadi kepala SD Muhammadiyah 2 Pangkalpinang. Pada masa kepemimpinanya ia membuka akses jalan masuk dan keluar dari SD Muhammadiyah 2 yang sebelumnya hanya satu. Menjadi satu disini bukan satu gerbang, akan tetapi satu pagar atau tembok dengan 2 pintu yang digunakan, yakni 1 untuk SD Muhammadiyah 1 Pangkalpinang dan satunya untuk SD Muhammadiyah 2 Pangkalpinang, kiri dan kanan seperti itu pembagiannya waktu itu. Hal ini menjadi salah satu kendala untuk mengatur siswa yang terlambat masuk dan juga ketika akses keluar masuk SD Muhammadiyah 1 Pangkalpinang itu lebih unggul karena bertepatan didepan atau lebih terlihat dari jalan raya. Juga kesulitan untuk memberikan pengumuman khusus untuk SD Muhammadiyah 2 Pangkalpinang. Jadi seperti satu lembaga didalam 2 kepengurusan. Hal tersebut sangat tidak kondusif.

Beberapa tahun kemudian seiring berjalannya pendidikan di SD Muhammadiyah 2 Pangkalpinang ini sesudah selesaikanya jalan dan kantor baru. SD Muhammadiyah 2 Pangkalpinang mengalami kenaikan atau kemajuan dalam administrasi dan juga kenaikan mutu dan siswa bertambah dan hampir menyamai SD Muhammadiyah 1 Pangkalpinang yang bertepatan di sebelahnya. SD Muhammadiyah 2 Pangkalpinag terus berkembang bahkan lebih unggul dari SD Muhammdiyah 1 Pangkalpinang. Keunggulan diantaranya terkait, administrasi sekolah, prestasi sekolah, jumlah siswa namun karena keterbatasan kelas maka hanya sanggup menerima 2 kelas saja di kelas 1 . Upaya penambahan ruang kelas ini pernah dilakukan dengan pernah mengajukan pembangunan kelas baru kepada bapak Kamaruddin AK selaku wakil pimpinan Muhammadiyah Daerah Bangka Belitung. Bahkan saya juga pernah mengusulkan untuk SD Muhammadiyah 2 Pangkalpinang ini dipindah berdasarkan peningkatan jumlah siswa dan membutuhkan sarana yang lebih memadai menggunakan tanah wakaf $H$. Siwarno yang mewakafkan lahannya supaya digunakan untuk pendidikan Muhammadiyah. Dan berjarah sekitar 200 meter dari SD Muhammadiyah 2 Pangkalpinang, akan tetapi tidak diijinkan hingga Bapak Supanut menyelesaikan masa kerjanya di SD Muhammadiyah 2 tahun 1992 dan dipindah ke ke SMP Muhammadiyah Pangkalpinang menjabat sebagai wakil kepala sekolah.

Pada tahun 1990-an, SD Muhammadiyah 1 Pangkalpinang dan SD Muhammadiyah 2 Pangkalpinang mengalami penurunan dalam kepengurusan dan juga dari jumlah siswa. Hal ini disebabkan diantaranya faktor waktu pelaksanaan pembelajaran dimana kegiatan pembelajaran dilaksanakan pagi dan sore, siswa yang belajar berbeda, guru yang mengajar juga berbeda. Awalnya pola pembelajaran pagi dan sore ini sangat baik akan tetapi tidak semua pihak menyetujui pelaksanaan sekolah di jam sore. Pandangan masyarakat tentang pelaksanaan sekolah di waktu sore tidak bertahan lama, karena kebanyakan orang tua sibuk di jam pagi sampai siang, sehingga lebih baik jika sekolah itu dilaksanakan pagi hari sampai siang. hal tersebut dilakukan karena pembelajaran yang tidak efektif dan kurangnya dukungan dari orang tua siswa jika dilaksanakan di siang sampai sore pembelajarannya.

Disamping itu juga terjadi kenyataan diantara dua SD Muhammadiyah tersebut saling bersaing dalam prestasi. Persaingan dalam akademis itu bagus, akan tetapi kenyataannya ada sisi negatif dalam persaingan 
tersebut. Permasalahan yang berkaitan dengan terjadinya penggabungan SD Muhammadiyah 1 dan SD Muhammadiyah 2 di Pangkalpinang selain yang telah disebutkan diatas juga ada permasalahan lain seperti jika ada konflik di siswa SD Muhammadiyah 1 dan SD Muhammadiyah 2 yang seharusnya cukup di siswa saja penyelesaiaannya tetapi guru-guru antara dua belah pihak ikut campur. Sehingga permasalahan yang seharusnya itu cukup untuk diselesaikan secara mudah dan ringan menjadi besar dan melebar kemanamana.

Untuk itu berdasarkan hasil diskusi dengan pimpinan dan juga majelis mengenai kendala, kondisi, dan manfaatnya yang terjadi diantara SD Muhammadiyah 1 dan SD Muhammadiyah 2 Pangkalpinang. Maka didapatlah keputusan dan atas persetujuan dari pimpinan, Majlis dan juga kedua kepala sekolah. Bahwa pada tahun 1997 SD Muhammadiyah 1 Pangkalpinang dan SD Muhammadiyah 2 Pangkalpinang di gabung dan menjadi SD Muhammadiyah Pangkalpinang. Penggabungan SD Muhammadiyah tersebut pastinya memerlukan kepala sekolah yang dapat menyatukan pemikiran maupun ideologi dari guru-guru dari dua SD Muhammadiyah terserbut. Sehingga sangat diperlukan untuk menyatukan kembali atau mengakrabkan dan mengarahkan kepada tujuan baru dari badan yang baru juga walaupun orang-orang didalamnya tidak baru.

Kepala sekolah yang lebih berpengalaman karena akan menyatukan dua belah pihak yang sebelumnya terjadi miskomunikasi dan yang lainnya. Bangunan sekolah, ruang kelas, ruang kantor, lapangan, kamar mandi, dan sarana lain. Tetap akan digunakan sebagai mana mestinya. Dan juga siswa juga akan lebih banyak lagi dari sebelumnya. Penggabungan sekolah ini pastinya memerlukan kerja keras untuk dapat membuat atau menata ulang sistem dan administrasi sekolah. Supaya Sekolah Dasar Muhammadiyah yang baru itu dapat berjalan dengan baik. (Waston \& Taryanto, 2019) Tujuan dan juga visi dan misi sekolah Muhammadiyah ditata ulang.

Rehab sekolah pernah dilakukan pada masa kepemimpinan Bapak Rudi Sutarmo, S.E (lahir di Kota Pangkalpinang pada tanggal 6 Bulan Desember Tahun 1967). Sebelum menjabat kepala sekolah tahun 2013 2017, Bapak Rudi Sutarno menjadi guru di SD Muhammadiyah Pangkapinang sejak tahun 2005 dan juga pernah menjadi wakil kepala sekolah. Pengalaman Bapak Sutarmo selama menjadi guru di SD Muhammadiyah Pangkalpinang merupakan pengalaman yang sangat berarti. Karena merasakan betul perjuangan untuk tetap bisa bertahan di SD Muhammadiyah Pangkalpinang sampai sekarang menjadi guru kembali di tahun 2019.

Perkembangan sekolah dari kepengurusan bapak Rudi Sutarmo, pada waktu itu bertepatan pada tahun 2016 mendapat dana bantuan dari pemerintah berupa perbaikan atau rehap gedung sekolah, lantai di tinggikan, cat sekolah, meja dan kursi untuk belajar sebanyak 6 ruang kelas. Sayangnya kondisi ini tidak bertahan lama karena tahun 2016 Kota Pangkalpinang diterjang banjir dimana wilayah sekolah ini menjadi terdampak paling parah saat banjir. Banjir di daerah ini setinggi leher orang dewasa kurang lebih setinggi 1 meter. Sehingga pada waktu itu keadaan sekolah yang baru, dengan penampilan baru, seperti cat yang baru, meja dan kursi yang baru. Akhirnya setelah banjir kursi dan meja menjadi rusak. Karena bahan dari meja dan kursi terbuat dari bahan kaju yang dipadatkan sehingga jika terkena atau tergenang air selama beberapa jam atau bahkan beberapa hari menjadi rusak. Walaupun tidak semua rusak karena masih ada yang bisa dipakai sampai sekarang.

Banjir yang datang pada tahun 2016 banyak merusak banyak sekali barang-barang penting sekolah. Seperti meja dan kursi menjadi rusak, dokumen-dokumen yang paling parah karena tidak tahan air. Dokumen yang rusak dan tidak dapat diperbarui kecuali diganti dengan dokumen baru seperti, buku-buku pelajaran anak-anak, buku-buku yang ada di perpustakaan, dokumen guru-guru atau administrasi guru dan sekolah, dan juga dokumen penting terkait ijazah alumni-alumni sebelumnya dan lain sebagainya. Dan sampai sekarang untuk memulihkan dokumen tersebut masih belum selesai atau belum lengkap. Karena dokumen-dokumen terdahulu tidak bisa diulang lagi dan harus dibuat dengan yang baru dengan kondisi yang ada pada sekarang di tahun setelah terjadi bencana bajir yaitu tahun 2017.

Bantuan dari pihak pemerintah daerah berupa buku-buku perpustakaan diberikan setelah kejadian banjir. Dan juga dari Majlis mulai memberikan perhatian setelah kejadian bencana banjir ini. Pemberian dana bantuan tersebut digunakan untuk melengkapi kembali dokumen buku-buku dan juga sarana dan prasarana di SD Muhammadiyah Pangkalpinang yang rusak. Walaupun pemberian tidak sepenuhnya dapt menutupi kekurangan dari seluruh dokumen dan barang-barang lain yang rusak tetapi dari pihak sekolah sudah bersyukur atas bantuan-bantuan yang ddiberikan, karena juga dapat mengurangi beban sekolah. (Menengah \& Negeri, 2008) bantuan lain yang diberikan juga berupa dana BOS dari pemerinta untuk melengkapi barang-barang yang hilang terkena benccana. 


\section{Pengelolaan Manajemen Sekolah}

Saat ini kepemimpinan dipegang oleh Bapak Harnandi yang juga alumni SD ini tahun 1979. Dikatakan Bapak Harnandi bahwa tatanan bangunan dari dulu tahun 1979 sampai 2019 tidak banyak berubah, hanya ada tambahan dua bangunan di bagian depan yang sekarang menjadi ruang administrasi dan ruang kelas yang sekarang digunakan untuk PAUD Aisyiah dan ruang PAUD sekarang menjadi SD Muhammadiyah, bentuknya masih sama. Bapak Harnandi diperbantukan menjadi kepala sekolah sejak tahun 2017, dengan landasan SD Muhammadiyah ini sebagai almamater beliau, maka dengan niat Lillahita'ala ingin membantu untuk memajukan sekolah ini, sampai awal penugasan tidak ada perubahan.

Awal mula menjabat menjadi kepala sekolah yang dilakukan adalah mulai membenahi sistem, membangkitkan SD Muhammadiyah Pangkalpinang ini supaya lebih maju lagi, oleh karena itu langkah awal yang dilakukan yakni memperbaiki sistem. Pembangunan sekolah itu penting dengan adanya perbaikan sistem, sistem yang pertama diperbaiki yakni SDM di Sekolah, (wijaya, 2009) SDM disini berkaitan dengan kepegawaian atau pengajar dalam berdisiplin, yakni tingkat kedisiplinan guru dan juga pegawai masih rendah.

Sistem atau peraturan yang ditegakkan ini berdampak kepada pelaku yang menyimpang dari peraturan, seperti ada beberapa waktu lalu ada siswa dikeluarkan karena tidak mengikuti peraturan, jadi bukan kami yang mengeluarkan tetapi sistem yang mengeluarkan. Kejadian dikeluarkannya siswa kami karena beberapa hari tidak masuk dan tidak ada keterangan, kemudian ditelusuri lagi ada kejadian yang memang tetap kami pindahkan ke sekolah lain dan atas persetujuan wali murid. Akan tetapi tidak hanya siswa, bahkan guru juga ada yang diluarkan, karena kejadian juga guru meninggalkan kelasnya tanpa ijin, meninggalkan kelas tidak hanya sehari dua hari, akan tetapi berhari-hari sampai lima hari, tanpa ijin ke pihak sekolah, pertama kami beri peringatan, kedua kami beri sanksi, dan terus berulang dan akhirnya kami dengan landasan peraturan kami keluarkan guru tersebut. Bagaimana tidak dikeluarkan jika ada guru yang tidak dapat membina siswanya untuk jadi lebih baik, bahkan sebaliknya. Maka dari itu dari kami juga harus bisa berbuat tegas untuk masalah tersebut.

SD Muhammadiyah Pangkalpinang ini tidak selalu memilih anak-anak yang terbaik dari segi penerimaan peserta didik baru, akan tetapi dari semua golongan kami terima. Karena dasarnya semua anakanak itu memiliki bakatmnya masing-masing (Cahyaningsih, 2011) tinggal kita sebagai guru dan pengajar itu mengarahkan saja. Kecuali anak-anak yang benar kita tidak mampu, seperti anak yang notabennya rendah, sehingga setelah ita diskusikan jika memang tidak mampu belajar di SD Muhammadiyah ini maka tidak diterima, akan tetapi selain itu kami terima. Kami memang tidak ada tes berhitung atau yang lain, akan tetapi kami tes bukan untuk kepandaiannya akan tetapi kami tes dalam segi mentalnya. Apakah mentalnya baik untuk mulai belajar di SD Muhammadiyah ini. Bukan karena belum bisa membaca bukan karena bisa berhitung. Tetapi mentalnya kemampuanya atau kemauannya untuk mau belajar itu sudah ada, dan kami bekerja sama dengan psikologi tes untuk membantu membagikan tingkatan kelas dan tingkatan kemampuan, dan juga kemampuan siswa yang perlu didampingi.

Pembagian kelas pada waktu penerimaan siswa baru, kami bagi menjadi tiga kelas, yaitu kelas A, B, dan C. Dengan kriterian sangat bagus, baik, dan cukup. Untuk penempatan dari kriteria tersebut, kami memiliki cara tersendiri. Kami tau jika pandangan masyarakat itu jika anaknya atai siswa di tempatkan dikelas A itu berarti siswa tersebut bagus atau baik dalam pendidikannya, sehingga kami berinisiatif bahwa penempatan itu kami rubah, siswa yang memerlukan bantuan khusus dalam pembelajaran kami tempatkan di kelas A dan di kelas B kelas dengan siswa sedang, dan di kelas $C$ yakitu siswa yang sangat baik dari sisi akademisnya. Sehingga pandangan wali murid ataupun masyarakat itu dapat membantu dan menerima dengan senang hati. Setiap kelas di dampingi 2 orang guru kecuali kelas B. Kelas kami akan memiliki brand yaitu minat dan bakat, cerdas amanah, dan mencerahkan. Untuk menyemangati guru-guru dan siswa juga dalam pembelajaran. karena nanti jika ada kegiatan-kegiatan tambahan diluar pembelajaran di kelas pasti akan ada yang namanya slogan-slogan untuk memasarkan atau mempromosikan SD Muhamadiyah Pangkalpinang ini.

Kepengurusan bapak Harnandi menyatakan terkait pengembangan SD Muhammadiyah Pangkalpinang. Anak-anak SD itu berbeda dengan anak-anak SMP, maka kami berfikir anak-anak SD kami berikan banyak permainan akan tetapi juga diselingi dengan belajar (Holis, 2006). Dengan adanya kurikulum 2013 ini kami sangat merasa terbantu dan setuju untuk menjalankannya, karena di kurikulum 2013 ini mengedepankan karanter sikap priritual, dan kami juga membuat program untuk anak-anak kami bisa menhafal jus 30 dari kelas 1 sampai kelas 6 atau lulus dari SD Muhammadiyah Pangkalpinang ini. Tetapi kami masih bertahap jadi tidak harus semuanya dihafal walaupun kami berharap bisa dihafal, jadi 
kalaupun siswanya hanya menghafal 70 persen atau 80 persen kami sudah bersyukur. Karena nantinya anaanak ini akan menjadi kepala rumah tangga, jadi ya harus dibelajari sejak dini untuk dapat menghafal suratsurat pendek.

Program unggulan salah satunya adalah hafalan juz $30 \mathrm{itu}$, akan tetapi juga program kurikulum ISMUBA Al Islam Kemuhammadiyahan dan Bahasa Arab, nantinya akan kami terapkan secara serentak ditahun berikutnya ini. Tetapi sekarang sudah diterapkan hanya saja belum kesemua kelas. Karena harus bertahap. (Lismawati \& Fahmi, 2019) Penerapan ISMUBA ini juga harus didukung tingkat kemahaman dan hafalan surat-surat pendek dari anak tersebut, supaya nantinya anak-anak dapat mengikuti tahap-tahap pembelajaran ISMUBA dengan mudah. Dan kami buat bukunya supada dapat dikontrol di sekolah dan juga di rumah. Karena kami juga membuat rapot pendukung dari hasil hafalan. nProgram lain yakni dengan setiap hari jumat kami memberikan hadist untuk kegiatan sunnah rosul seperti makan dan minum sambil duduk, menggunakan tangan kanan. Dan juga setiap hari kamis kami memberikan program hari sehat makan buah, jadi aak-anak kami anjurkan untuk membawa buah, dan buahnya bebas, boleh semangat 1 potong, atau apel, jeruh, pisang, terserah anak-anak yang membawa, yang terpenting buah. Karena makanan kita semua banyak makanan cepat saji, maka dari itu kurang makanan berserat. Dengan adanya program ini kami akan membentuk karakter makan buah sejak dini. Supaya anak-anak itu terbiasa makan makanan sehat.

Bapak Harnandi juga membuat paguyuban kelas bagi orang tua siswa atau walimurid yang tersistem, dengan adanya ketua sekretaris bendahara. Sehingga nanti jika ada hal-hal tertentu seperti kemaren program mengecat kelas atau menghias kelas, jika kami gunakan dana mandiri dari sekolah kami tidak sanggup, akhirnya kami diskusikan dengan paguyuban di masing-masing kelas tersebut dan mendapat respon baik. Dan akhirnya ada dana bantuan dari setia paguyuban kelas untuk membantu menghias kelas dari masingmasing paguyuban. Karena tujuan dari menghias kelas ini supaya anak-anak didalam kelas saat belajar supaya semangat dan senang jika masuk ruang kelas tersebut. Dan juga kami adakan lomba bagi kelas yang meenghiasnya paling bagus. Ada yang habis 3 juta dan 2 juta, maka kami merasa terbantu. Sehingga manfaat dari dana tersebut juga dirasakan oleh siswa-siswa tersebut.

Program TPMPS Tim Penjamin Mutu Pendidikan Sekolah ada 8 orang yang memgang 8 standar, Kelulusan, Isi, Proses, Sarana prasaranan, Pendidikan, Kelulusan. Maka dari itu harus lebih ditekankan. Karena kepala sekolah tidak dapat berjalan sendiri, maka kami perlu bantuan dari TPMPS tersebut. Karena dengan adanya kepala sekolah dan TPMPS ini kami berjuang bersama untuk memajukan sekolah, akan tetapi jika kepala sekolah bekerja sendiri dan merasa bahwa dirinya bisa, maka tunggu saja, pasti lambat laun akan merosot.

Pada tahu 2016 penerimaan siswa baru hanya 2 kelas dan itu mengalami penurunan dari tahun-tahun sebelumnya. Dengan kejadian tersebut kami tergugah untuk lebih semangat lagi memperbaiki sistem. Karena orang tua yang menilai, orang tua yang menitipkan anak-anaknya di SD ini, dan secara tidak langsung SD Muhammadiyah Pangkalpinang ini dipercaya untuk membuat anaknya itu berkembang menjadi lebih baik lagi. Maka dari itu kami selaku guru dan pegawai harus bisa menanggapi tanggungjawab tersebut. Hal tersebut yang kami sebut dengan memperbaiki sistem dan menambahkan program-program unggulan. Program-program tersebut dapat dirasakan dengan adanya peningkatan pendaftaran siswa baru, yang mana tahun 2017 sebanyak dua kelas, kemudian tahun 2018 sebanyak empat kelas, karena ada 1 kelas yang kosong sehingga kami bisa menerima 4 kelas, dan tahun ini 2019 kami menerima 3 kelas atau normalnya kami sanggup menerima kelas segitu karena keterbatasan ruangnnya. Kepala sekolah harus berani untuk membuat sistem dengan aturan tersebut.

Dibawah Kepemimpinan Bapak Harnandi, peraturan atau tingkat kedisiplinan dalam pembelajaran, dampaknya dua tahun terakhir ini pendaftaran siswa baru meningkat dan malahan di tahun terakhir ini menolak siswa karena terlalu banyak yang menadaftar sementara ruang kelas masih kurang sehingga hanya menerima 3 kelas saja untuk kelas 1 . Tahun pertama menjadi Ketua PPDP dan ada program untuk menjual sekolah maksudnya memasarkan sekolah ini lebih baik lagi dengan program-program unggulan yang dikenalkan kepada masyarakat. Kemudian ditahun kedua kami menolak siswa karena terlalu banyak yang daftar dan hampir 1 kelas siswa yang ditolak, dan itu menjadi PR atau tugas kami selanjutnya untuk menambah kelas lagi. Supaya ditahun berikutnya bisa menerima siswa yang mau bersekolah disini.

Daya tarik masyarakat terhadap SD Muhammadiyah itu terdapat pada mata pelajaran agama dan juga prestasi dari alumni SD Muhammadiyah bagus (Susanti et al., 2017). Dengan adanya poin khusus ini siswa SD Muhammadiyah mengalami peningkatan setiap tahunnya. Sampai pada tahun 2000an siswa SD Muhammadiyah mulai membatasi input dari siswa yang mendaftar. Bahkan sampai anak cucuk dari alumni 
SD Muhammadiyah mensekolahkan anak cucunya di SD Muhammadiyah. Karena pandangan masyarakat sudah baik dan memang menjadi rekomendasi untuk anak-anak dari masyarakat untuk bersekolah. Alumni secara khusus tidak ada keterkaitan yang benar-benar jelas, akan tetapi ada eberapa alumni yang masih ada komunikasi untuk saling membantu dalam pembangunan pembangunan sekolah.

\section{Kesimpulan}

SD Muhammadiyah Pangkalpinang merupakan SD Muhammadiyah tertua yang ada di Bangka Belitung atau disebut sebagai Bumi Serumpun Sebalai berdiri sejak tahun 1960 masehi, pengurus awal SD Muhammadiyah diantaranya Ibu Akmar orang padang. Materi ajar, sarpras yang ada menyesuaikan dan berkembang seiring berjelannya waktu, 1980-an perkembangan SD Muhammadiyah Pangkalpinang semakin baik, program kegiatan yang diberikan seperti program harian seperti membaca al-Quran setiap pagi, program mingguan kajian setiap hari jumat, dan program tahunan seperti outing class telah diberikan dan berkembang seiring waktu. Kendala yang menjadi sejarah besar yakni terjadinya pemisahan sekolah Muhammadiyah menjadi SD Muhammadiyah 1 dan SD Muhammadiyah 2 pada tahun 1982 sampai pada tahun 1992 SD Muhammadiyah 1 dan SD Muhammadiyah 2 digabung kembali menjadi SD Muhammadiyah Pangkalpinang. Terjadinya banjir besar pada tahun 2016 yang mengakibatkan kerusakan sarana dan prasarana Sekolah. Pengelolaan sekolah sangat beragam dengan adanya pergantian kepala sekolah yang berkesinambungan sampai dengan sekarang oleh Bapak Harnandi alumni dari SD Muhammadiyah Pangkalpinang tahun 1979, memperbaiki system sekolah yang menurun seperti SDM Sekolah, tingkat kedisiplinan, dan program tambahan seperti hadis mingguan, sehat buah, bersih lingkungan, Outbont, pembagian kelas di awal penerimaan siswa baru.

\section{Referensi}

Anshori, S. (2016). Strategi pembelajaran di era digital (tantangan profesionalisme guru di era digital). Artikel.

Azimmi, N. (2019). PERAN GURU PPKn SELAKU BUNDO KANDUANG DALAM MEMBANGUN KARAKTER PESERTA DIDIK DI SEKOLAH. Journal of Civic Education. https://doi.org/10.24036/jce.v2i2.128

Cahyaningsih, S. D. (2011). Pertumbuhan Perkembangan Anak dan Remaja. Cv. Trans Info Media.

Dahlan, M. (2014). K.H. AHMAD DAHLAN SEBAGAI TOKOH PEMBAHARU. Jurnal Adabiyah.

Danil, D. (2009). Upaya Profesionalisme Guru Dalam Meningkatkan Prestasi Siswa di Sekolah (Study Deskriptif Lapangan di Sekolah Madrasah Aliyah Cilawu Garut ). Jurnal Pendidikan.

Hadi, A. (2005). Gerakan Pemikiran Muhammadiyah dari Puritanisme ke Dinamisme. Fakultas Syari'ah IAIN Sunan Ampel Surabaya.

Holis, A. (2006). Belajar Melalui Bermain untuk Pengembangan Kreativitas dan Kognitif Anak Usia Dini. Pendidikan Universitas Garut. https://doi.org/10.1142/9789812773678_0145

Lismawati, L., \& Fahmi, A. K. (2019). ANALISIS BUTIR SOAL ISMUBA (AL-ISLAM KEMUHAMMADIYAHAN DAN BAHASA ARAB) KELAS IV SD MUHAMMADIYAH 5 JAKARTA SELATAN. Jurnal Pendidikan Islam. https://doi.org/10.22236/jpi.v10i1.3452

Mafidin. (2012). STUDI LITERATUR TENTANG PERAN MUHAMMADIYAH DALAM MENGEMBANGKAN PENDIDIKAN ISLAM DI INDONESIA Oleh : Mafidin. Jurnal Tarbawi, $1(1)$, 43-53. http://jurnal.upi.edu/file/05_Studi_Literatur_Tentang_Peran_Muhammadiyah_Dalam_Mengemba ngkan_Pendidikan_Islam_Di_Indonesia_-_Mapidin.pdf

Menengah, S., \& Negeri, P. (2008). Evaluasi Pelaksanaan Program Bantuan Operasional Sekolah ( Bos ). Pasca Sarjana UnDip.

Somantri, G. R. (2005). MEMAHAMI METODE KUALITATIF. Makara Human Behavior Studies in Asia. https://doi.org/10.7454/mssh.v9i2.122

Susanti, A. D., Muslihudin, M., \& Hartati, S. (2017). Sistem Pendukung Keputusan Perankingan Calon Siswa Baru Jalur Undangan Menggunakan Simple Additive Weighting (Studi Kasus : Smk Bumi Nusantara Wonosobo). Seminar Nasional Teknologi Informasi Dan Multimedia 2017. 
Waston, W., \& Taryanto, T. (2019). PERAN KEPALA SEKOLAH DALAM MENINGKATKAN MUTU PENDIDIKAN DI SEKOLAH DASAR ISLAM TERPADU MUHAMMADIYAH JUMAPOLO KARANGANYAR. Profetika Surnal Studi Islam. https://doi.org/10.23917/profetika.v0i0.8949

wijaya, davit. (2009). Manajemen Sumber Daya Manusia Pendidikan Berbasis Kompetensi Guru dalam Rangka Membangun Keunggulan Bersaing Sekolah. Pendidikan.

Zalik Nuryana. (2017). Revitalisasi Pendidikan al Islam dan Kemuhammadiyahan pada Perguruan Muhammadiyah. TAMADDUN. 